Published in final edited form as:

Neurochem Res. 2010 October ; 35(10): 1643-1651. doi:10.1007/s11064-010-0225-0.

\title{
Effect of NRG1, GDNF, EGF and NGF in the Migration of a Schwann Cell Precursor Line
}

\author{
Martha Cornejo, \\ Department of Biology, California State University Northridge, MC 8303.18111 Nordhoff Street, \\ Northridge, CA 91330, USA \\ Deborah Nambi, \\ Department of Biology, California State University Northridge, MC 8303.18111 Nordhoff Street, \\ Northridge, CA 91330, USA \\ Christopher Walheim, \\ Department of Biology, California State University Northridge, MC 8303.18111 Nordhoff Street, \\ Northridge, CA 91330, USA
}

\author{
Matthew Somerville, \\ Department of Biology, California State University Northridge, MC 8303.18111 Nordhoff Street, \\ Northridge, CA 91330, USA \\ Jacquae Walker, \\ Department of Biology, California State University Northridge, MC 8303.18111 Nordhoff Street, \\ Northridge, CA 91330, USA
}

\section{Lino Kim,}

Department of Biology, California State University Northridge, MC 8303.18111 Nordhoff Street, Northridge, CA 91330, USA

\section{Lauren Ollison,}

Department of Biology, California State University Northridge, MC 8303.18111 Nordhoff Street, Northridge, CA 91330, USA

\section{Graciel Diamante,}

Department of Biology, California State University Northridge, MC 8303.18111 Nordhoff Street, Northridge, CA 91330, USA

\section{Saurabh Vyawahare, and}

Division of Biology, California Institute of Technology, 139-74, Pasadena, CA 91125, USA

\section{Maria Elena de Bellard}

Department of Biology, California State University Northridge, MC 8303.18111 Nordhoff Street, Northridge, CA 91330, USA

Maria Elena de Bellard: maria.debellard@csun.edu

\section{Abstract}

The Schwann cells are the myelinating glia of the peripheral nervous system that originated during development from the highly motile neural crest. However, we do not know what the guidance signals for the Schwann cell precursors are. Therefore, we set to test some of the known

\footnotetext{
(c) Springer Science+Business Media, LLC 2010

Correspondence to: Maria Elena de Bellard, maria. debellard@ csun. edu.

Martha Cornejo, Deborah Nambi and Christopher Walheim these authors contributed equally.
} 
neurotrophins that are expressed early in developing embryos and have been shown to be critical for the survival and patterning of developing glia and neurons. The goal of this study was to determine more specifically if GDNF, NRG1 and NGF are chemoattractants and/or chemokinetic molecules for a Schwann cell precursor line, the Spl201. We performed live chemoattraction assays, with imaging and also presented these molecules as part of their growing substrate. Our results show for the first time that GDNF and NRG1 are potent chemoattractive and chemokinetic molecules for these cells while NGF is a chemokinetic molecule stimulating their motility.

\section{Keywords}

Schwann cell precursors; NeuregulinB1; NGF; GDNF; Cell migration; Chemoattraction

\section{Introduction}

The development of the nervous system is a fascinating process involving cell induction, determination and movement. In the embryo, neural crest cells are amongst the most motile and persistent, starting with a transformation from an epithelial to a mesenchymal cell in the neural tube, to becoming a heterogeneous population that migrates quickly and extensively throughout the early developing embryo. The neural crest gives rise to a wide variety of cells amongst which is the peripheral glia: Schwann cells [1,2]. Therefore, Schwann cells derive from a population of cells that initially have stem cell properties and are highly motile $[1,3,4]$.

Developing Schwann cell precursors encounter a rich environment during their migration into the embryo tissues [5]. Along this path they encounter signals (extracellular matrix proteins, membrane associated as well as secreted guidance molecules) that likely guide them to their targets [6,7]. However, it has not been tested and proven if Schwann cell precursors (SCPs) migrate using diffusible signals to reach their targets, as is the case with axon elongation [8], though there are implicit indications that they do [9, 10]. First, neural crest cells and later on, SCPs are capable of migrating in the absence of axons [10,11]. Second, time-lapse of zebrafish labeled neural crest/SCPs showed that these cells reach their targets without axons and even tow axons along the lateral line $[12,13]$. These observations underscore that SCPs are capable of sensing and finding independently the proper cues when reaching their targets. Third, erbB3 receptor knockout mice and zebrafish have severe Schwann cell development phenotypes [14-16]. Fourth, SCPs have been shown to migrate close to growing axons in the developing limb, thus suggesting that both might be following the same diffusible signals to their targets [9].

Despite this wealth of findings, we still do not know: (1) a single signal molecule clearly responsible for SCP guided migration, as we know for growth cone guidance [7]. (2) If the chemotrophic signals (neurotrophins) involved in determining the fate of SCPs are also involved in their migration and (3) if these molecules, which provide chemotactic and chemokinetic signals to growing axons are also capable of attracting and stimulating the motility of Schwann cell precursors.

In order to preliminarily answer these questions we turned to a cell line with a phenotype intermediate between neural crest and Schwann cell precursors [17, 18]. In our search for candidate diffusible molecules, we focused on the neurotrophins already implicated in Schwann cell development: Glia derived neurotrophic factor (GDNF), neuregulin beta-1 (NRG1) and nerve growth factor (NGF) which are expressed early in development along paths traversed by the Schwann cell precursor and whose receptors are known to be expressed by these cells during the period of their active migration along axons [5]. Our 
preliminary data suggests that GDNF and NRG1 are chemotactic (attractant) and chemokinetic molecules for SCPs and that NGF has just chemokinetic effects.

\section{Experimental Procedures}

\section{In Vitro Chemoattraction of Neurotrophins}

In these experiments SpL201 $(125,000)$ were plated on the upper side of a chemotatic (Millipore) chamber with $200 \mathrm{ng} / \mathrm{ml}$ in the lower chamber to create a gradient steep enough for chemotaxis [19]. After $5 \mathrm{~h}$ the cells on the upper side of the filter were removed and cells on the bottom side fixed with 4\% Paraformaldehyde (PFA) and stained with toluidine blue. Cells were expanded and grown in feeding media: DMEM (Gibco), $10 \%$ fetal bovine serum, $2 \mathrm{mM}$ L-glutamine, and antibiotics (Omega) plus $10 \mathrm{ng} / \mathrm{ml}$ of EGF. Two days prior to the experiments, cells were deprived of EGF.

\section{Time Lapse Video Microscopy}

Cells were cultured on Ibidi micro-slides in DMEM/10\%FBS. Next day cells were exposed to a focal source of neurotrophin and imaged in a Zeiss $35 \mathrm{M}$ at 90 s intervals for $3 \mathrm{~h}$ [20]. The captured images were converted into an ImageJ movie and analyzed using the Ibidi pluggin for tracking individual cells.

\section{Micro-Chip Preparation Assay}

The chips for patterning proteins are prepared by the Caltech Microfluidic Foundry (www.kni.caltech.edu/foundry). The chips were cut out and thermally bonded at $80^{\circ} \mathrm{C}$ to an epoxy coated glass slide (Arrayit Corporation) for a few hours. Connectors were inserted then peristaltic tubing is attached and proteins in a non-reactive buffer were flown through at low pressures (1-3 psi). After allowing for a few minutes of reaction time, the remaining solution was flushed out with buffer. The exact amount of protein bonding to the surface can be controlled by using a mix of the protein of interest and bovine serum albumin in different ratios.

\section{Micro-Chip Assay}

SpL201 re-suspended in Fibronectin $(100 \mu \mathrm{g} / \mathrm{ml})$ were plated at $70-80 \%$ confluence over the micro-chips coated with neurotrophins for $2 \mathrm{~h}$, and then the tissue culture dish was filled with feeding media for 3 more hours. We then took phase contrast pictures and returned cells to incubator for $12 \mathrm{~h}$. Cultures were fixed in $4 \%$ PFA and stained with toluidine blue to visualize the cells.

\section{Wound Assay}

SpL201 cells were allowed to grow onto 90\% confluence overnight and next day monolayer's were wound by scrapping with a pipette tip [21,22]. Culture media was replaced with feeding media or with media containing neurotrophins; cells were allowed to migrate for $5 \mathrm{hsr}$ before fixing with $4 \%$ PFA and staining with toluidine blue. We counted at least in 6-7 areas the number of cells that invaded the wound. Each experiment had a duplicate and the data corresponded to 5 experiments. Experiments were done in feeding media with $10 \%$ FBS or without any FBS.

\section{SpL201 Injection}

A cell suspension of SpL201 cells was incubated for 10 min with a $10 \mu \mathrm{M}$ solution of DiI a lipophillic fluorescent dye (Molecular Probes) and washed three times before being injecting the labeled cells using a mouth micro-pipette in HH15 chicken embryos. Cells were injected along the path were hosts neural crest cells migrate: between the neural tube and somites at 
the forelimb level. Next day embryos were fixed in 4\% PFA and the forelimb portion was cryosectioned and stained with HNK1 to label host's neural crest cells. Immunostained sections were mounted in permount after DAPI labeling of nuclei.

\section{Results}

\section{Characterizing SpL201 Cell Line}

The SpL201 is an immortalized Schwann cell precursor line that is capable of differentiating into fully myelinating Schwann cells [17]. We first characterized the SpL201 mouse cell line in order to determine the extent to which these cells correspond to a fully differentiated Schwann cell phenotype versus a more transient cell type before carrying out any migration assays. We found that $90 \%$ of these cells expressed classic Schwann cell precursor markers like Sox10, GFAP, S100, p75 and RIP (Fig. 1). However, not all cells were positive for these markers at the same time or to the same extent, underscoring that many of these cells are still transitioning between a neural crest and a glial phenotype. Further support to this came from looking also at these cells morphology. We never observed in these cells the classic spindle shape of differentiated Schwann cells [18, 23].

In addition, we also injected SpL201 vitally labeled with DiI into HH15 chicken embryos to determine their migratory capabilities in an in vivo environment. We found that these cells migrated along typical neural crest pathways (Fig. 2). We found DiI-labeled SpL201 cells along the ventromedial pathway, around the dorsal aorta, entering the gut (Fig. 2a and b), as well as in the dorsomedial pathway of melanocytes (between the ectoderm and dermomyotome) (Fig. 2b). Therefore, these SpL201 cells are capable of migrating as well and as speedily as neural crest cells.

\section{Chemoattraction Assays}

We looked for chemotactic response in SpL201 cells by culturing them in chemotaxis chambers in the presence of GDNF, NRG1, NGF and EGF (Fig. 3). In these experiments SpL201 cells were plated on the upper side of a chemotatic (Millipore) chamber with 200 $\mathrm{ng} / \mathrm{ml}$ of neurotrophins in the lower chamber. After $5 \mathrm{~h}$ of culture cells on the bottom side of the filter were counted (Fig. 3a). We observed that the SpL201 cells were strongly attracted (300\% more, $P<0.001$ T-test) to the wells where GDNF, NRG1 and EGF were present, while NGF did not have any effect on their migratory choice compared with control conditions (Fig. 3b).

To corroborate these findings we tested the same neurotrophins in a different assay. Here we exposed Schwann cell precursor SpL201 cells to a neurotrophin gradient in Zigmond like chambers [24] and then live imaged cell movements for $3 \mathrm{~h}$ (Fig. 4a). We found as with the chemotactic chambers, that SpL201 cells preferentially migrated towards GNDF and NRG1. In these experiments SpL201 cells showed a significant displacement toward the reservoir with GDNF $(P<0.05)$, although NRG1 did not give a statistically significant displacement compared with control (Fig. 4b). We used MIF (macrophage inhibitory factor) as a positive control since it is known to stimulate cell motility [25].

These results strongly suggested that GDNF and NRG1 were possible chemoattractant candidates for Schwann cell precursor line SpL201. We further tested this hypothesis by culturing these cells on top of surfaces coated with the neurotrophins as part of the substrate in a modified choice assay. This approach has been used successfully to analyze growth cone guidance and neural crest cell migration [26, 27]. This second assay consisted of exposing actively migrating cells to a microchip coated with neurotrophins to determine if they steer from their course and migrate preferentially towards the surfaces where the chemoattractant is present (Fig. 5a). The significance of this experiment stems from its 
advantage in distinguishing between cell chemoattraction (positive directional response towards a specific molecule) from cell chemotaxis (how dynamically a cell moves irrespective of its environment). Under these conditions cells are not exposed to a molecular gradient, but to a specific substrate. If cells show a preferential migration over the substrate when they encounter it (in this case as a part of the matrix over which they are growing, not in solution in the media) by having a strong tendency to remain within the channels carrying a particular neurotrophin, it will strongly suggest that they are attracted to it.

When we grew SpL201 on such microchips surfaces coated with neurotrophins we found that within $5 \mathrm{~h}$ of plating the Schwann cell precursor cell line preferentially moved over the lanes in the microchips that were coated with GDNF, and to a lesser degree to NRG1 lanes (Fig. 5a-c). Meanwhile, SpL201 cultured on top of NGF or EGF did not show any preferential attachment within the first $5 \mathrm{~h}$ (Fig. 5d, f). After $24 \mathrm{~h}$ of culture the SpL201 cells remained preferentially on top of the lanes that have GDNF and NRG1 (Fig. 6e, f) compared with control (Fig. 6d). We observed these results in 5/6 separate experiments. The data for NGF and EGF was not as conclusive: although there was no preferential response within the first $5 \mathrm{~h}$ of culture, next day we observed that SpL201 have moved over to the lanes with EGF or NGF in 3/6 experiments (data not shown). Fibronectin was used as a positive control and showed a strong positive effect on the SpL201 cells as expected for this extracellular matrix protein (Fig. 5e).

Altogether these experiments strongly support a chemoattractive role of GDNF and NRG1 for the Schwann cell precursor SpL201 cells. The results with EGF were not conclusive since soluble EGF attracted SpL201 (Fig. 2b) whereas EGF as a substrate was not capable of making the cells preferentially choose it over a Fibronectin substrate (Fig. 4d). We are planning to further test EGF in Ibidi chamber assays. NGF however, did not elicit a positive response in these cells in both assays.

\section{Migration Assays}

Because we are working with developing cells that are physiologically sensitive to neurotrophins, the first step towards determining that a certain molecule is a true chemoattractant during Schwann cell migration is to be able to distinguish cell migration towards a source/point (chemoattraction response), from enhanced cell migration (chemotaxis response) and from cell survival or survival/proliferation (trophic response). In the first assays we looked at simple chemoattractant response. In the next experiment we approached this complex problem of distinguishing cell motility with techniques commonly used to test if a specific molecule has a chemotactic effect on cells [28].

We performed classic wound assays with these cells to determine if they were capable of moving faster in the presence of soluble forms of these neurotrophins compared with control conditions. We observed that indeed GDNF, NRG1 and NGF were capable of enhancing the motility of the SpL201 cells after $5 \mathrm{~h}$ of wounding (Fig. 7). We used Slit2 as a positive control since it stimulates the motility of neural crest cells [29]. However, we did not find any change in SpL201 motility in the presence of EGF. We observed that the migratory response of these cells was strongly dependent on the absence of FBS in the media. We found that these cells will not increase their motility if serum was present in the media during the wound healing experiment, suggesting that already other factors present in the serum are also capable of enhancing their motility.

\section{Discussion}

Schwann cell precursor's cells, derive from the neural crest and are an interesting population due to their intermediary phenotype: not fully differentiated into mature peripheral glia, 
neither a stem cell as the neural crest; not as motile as crest cells themselves, neither as slow as its mature form. In this study we looked at the effect that GDNF, NRG1, EGF and NGF have on the guidance and motility of these cells. Our findings shows for the first time that GDNF and NRG1 are potent chemoattractants for a Schwann cell precursor cell line (SpL201) and that GDNF, NRG1 and NGF are potent migratory stimulants of these cells.

Cell migration is a complex phenomenon. Cells need to re-arrange their cytoskeleton, become polarized if they are responding to a guidance molecule, make adequate plasma membrane protrusions and simultaneously generate traction and retraction of the cell body. SCPs are known to migrate along developing nerves [30, 31] during the time when neurotrophins have been shown to be key players: they are expressed early during development and their absence causes disruption of axonal pathfinding or glial development [32-34]. Neurotrophin signaling still remains a very complex one because it is involved in mechanisms as distinct as the regulation of cell migration, cell proliferation, cell survival, and chemotaxis $[35,36]$. Research in the past 10 years has shown that NGF, NRG1 and GDNF both stimulate the motility and attract Schwann cells [37-41].

In summary: we know that NRG1, NGF and NT-3 are proven chemoattractants for mature Schwann cells. However, we do not know if these any molecules can have similar effects on SCPs themselves. Our findings that: (a) GDNF and NRG1 attract a Schwann cell precursor cell line and (b) that GDNF, NRG1 and NGF stimulated the motility of these cells as well, suggest that these molecules might be also guidance and chemokinetic molecules for embryonic precursors of Schwann cells. These results for a SCP cell line are underscored by preliminary data from our lab where we found that Schwann cell lines (SC1.17 and SW10) respond in a similar manner as SpL201 cells to the same neurotrophins by enhancing their motility, while NRG1 and GDNF will not stimulate the motility of the progenitor cells, the neural crest (data not shown).

GDNF was a strong chemoattractant candidate being the ligand for the GFRa1, NCAM and ret receptor; the last two are expressed by Schwann cells [38]. GNDF has been shown to enhance the motility and attract olfactory ensheathing glia [28]. Furthermore, mutations in the ligand or receptor cause severe deficits in the neural crest derived enteric nervous system and glia: enteric Schwann cells are not found in the gut, not from lack of trophic signals but from lack of proper guidance signals $[42,43]$. NRG1 whose erbB2/erbB3 family receptors are known to be crucial in Schwann cell development was another good candidate: Mice mutant for the erbB3 lacked proper Schwann cell precursor establishment [16, 44-47].

In our current study we found that GDNF and NRG1 are potent chemoattractants for the Schwann cell precursor SpL201 suggesting that it may also be a chemoattractant for developing SCPs as it is for mature Schwann cells. Recent studies have shown that the proliferative effects that erbB receptors have on Schwann cells can be separated from its effect on migration [14]. In our present study we found that NRG1 was also capable of stimulating SpL201 motility underscoring those genetic findings with our in vitro live assays and suggesting that NRG1 as GDNF may play a role in guiding Schwann cell precursors towards their targets.

Our preliminary results indicate that there was no preferential migration towards a source of NGF by the Schwann cell precursor SpL201 line in our chemotaxis assays or as in our substrate choice assay. However, we did observe that the SpL201 cells moved more rapidly in the presence of NGF in our wound assays, suggesting that NGF may stimulate cell motility while it did not show to be a chemoattractant for this precursor cell line in two of our assays, as it has already been reported for mature Schwann cells [39, 40]. This is an interesting finding because it is known that Schwann cells are attracted to NGF as well as 
growth cones [39, 40,48]. Our observation that SpL201 were not attracted to NGF, although they do respond to this molecule suggests that NGF may not play the same role during SCPs migration as for growth cones. However, because the concentration of NGF in the wounds assays was $200 \mathrm{ng} / \mathrm{ml}$ and at these high concentrations we are stimulating the p75 low affinity receptor, suggests that the enhanced motility of SpL201 is mediated by p75 NGF receptor.

In summary our results show that NRG and GDNF are chemoattractants and chemokinesis molecules for a Schwann cell precursor line (SpL201). This is the first time that some type of Schwann cell precursor is shown to respond to neurotrophins as guidance molecules and therefore supports a hypothetical role for these molecules in the developing peripheral nervous system, especially the enteric one. Finally our results stress the importance of looking more deeply into the role of neurotrophins as chemotactic molecules in Schwann cell precursors as well as mature cells.

\section{Acknowledgments}

We thank Sonsoles de Lacalle for help writing this manuscript. This work was partly supported by a NIH-MBRS SCORE-5S06GM048680-13 to MEdB.

\section{References}

1. Morrison SJ, White PM, Zock C, Anderson DJ. Prospective identification, isolation by flow cytometry, and in vivo self-renewal of multipotent mammalian neural crest stem cells. Cell. 1999; 96:737-749. [PubMed: 10089888]

2. Hagedorn L, Suter U, Sommer L. Po and PMP22 mark a multipotent neuralcrest-derived cell type that displays community effects in reponse to TGF-B family factors. Development. 1999; 126:3781-3794. [PubMed: 10433908]

3. Bronner-Fraser M, Fraser SE. Cell lineage analysis reveals multipotency of some avian neural crest cells. Nature. 1988; 335:161-164. [PubMed: 2457813]

4. Stemple DL, Anderson DJ. Isolation of a stem cell for neurons and glia from the mammalian neural crest. Cell. 1992; 71:973-985. [PubMed: 1458542]

5. Jessen KR, Mirsky R. Embryonic Schwann cell development: the biology of Schwann cell precursors and early Schwann cells. J Anat. 1997; 191(Pt 4):501-505. [PubMed: 9449069]

6. Branda CS, Stern MJ. Cell migration and axon growth cone guidance in Caenorhabditis elegans. Curr Opin Genet Dev. 1999; 9:479-484. [PubMed: 10449355]

7. Tessier-Lavigne M, Goodman CS. The molecular biology of axon guidance. Science. 1996; 274:1123-1133. [PubMed: 8895455]

8. Nieto MA. Molecular biology of axon guidance. Neuron. 1996; 17:1039-1048. [PubMed: 8982153]

9. Wanner IB, Mahoney J, Jessen KR, Wood PM, Bates M, Bunge MB. Invariant mantling of growth cones by Schwann cell precursors characterize growing peripheral nerve fronts. Glia. 2006; 54:424438. [PubMed: 16886207]

10. Bhattacharyya A, Brackenbury R, Ratner N. Axons arrest the migration of Schwann cell precursors. Development. 1994; 120:1411-1420. [PubMed: 8050352]

11. Bhattacharyya A, Frank E, Ratner N, Brackenbury R. P0 is an early marker of the Schwann cell lineage in chickens. Neuron. 1991; 7:831-844. [PubMed: 1720625]

12. Gilmour D, Knaut H, Maischein HM, Nusslein-Volhard C. Towing of sensory axons by their migrating target cells in vivo. Nat Neurosci. 2004; 7:491-492. [PubMed: 15097993]

13. Gilmour DT, Maischein HM, Nusslein-Volhard C. Migration and function of a glial subtype in the vertebrate peripheral nervous system. Neuron. 2002; 34:577-588. [PubMed: 12062041]

14. Lyons DA, Pogoda HM, Voas MG, Woods IG, Diamond B, Nix R, Arana N, Jacobs J, Talbot WS. erbB3 and erbB2 are essential for schwann cell migration and myelination in zebrafish. Curr Biol. 2005; 15:513-524. [PubMed: 15797019] 
15. Rosenbaum C, Karyala S, Marchionni MA, Kim HA, Krasnoselsky AL, Happel B, Isaacs I, Brackenbury R, Ratner N. Schwann cells express NDF and SMDF/n-ARIA mRNAs, secrete neuregulin, and show constitutive activation of erbB3 receptors: evidence for a neuregulin autocrine loop. Exp Neurol. 1997; 148:604-615. [PubMed: 9417836]

16. Riethmacher D, Sonnenberg-Riethmacher E, Brinkmann V, Yamaai T, Lewin GR, Birchmeier C. Severe neuropathies in mice with targeted mutations in the ErbB3 receptor. Nature. 1997; 389:725-730. [PubMed: 9338783]

17. Lobsiger CS, Smith PM, Buchstaller J, Schweitzer B, Franklin RJ, Suter U, Taylor V. SpL201: a conditionally immortalized Schwann cell precursor line that generates myelin. Glia. 2001; 36:3147. [PubMed: 11571782]

18. Buchstaller J, Sommer L, Bodmer M, Hoffmann R, Suter U, Mantei N. Efficient isolation and gene expression profiling of small numbers of neural crest stem cells and developing Schwann cells. J Neurosci. 2004; 24:2357-2365. [PubMed: 15014110]

19. Andrew N, Insall RH. Chemotaxis in shallow gradients is mediated independently of PtdIns 3kinase by biased choices between random protrusions. Nat Cell Biol. 2007; 9:193-200. [PubMed: 17220879]

20. Song H, Ming G, He Z, Lehmann M, McKerracher L, Tessier-Lavigne M, Poo M. Conversion of neuronal growth cone responses from repulsion to attraction by cyclic nucleotides. Science. 1998; 281:1515-1518. [PubMed: 9727979]

21. Entschladen F, Drell TLt, Lang K, Masur K, Palm D, Bastian P, Niggemann B, Zaenker KS. Analysis methods of human cell migration. Exp Cell Res. 2005; 307:418-426. [PubMed: 15950622]

22. Muller PA, Caswell PT, Doyle B, Iwanicki MP, Tan EH, Karim S, Lukashchuk N, Gillespie DA, Ludwig RL, Gosselin P, Cromer A, Brugge JS, Sansom OJ, Norman JC, Vousden KH. Mutant p53 drives invasion by promoting integrin recycling. Cell. 2009; 139:1327-1341. [PubMed: 20064378]

23. Brockes JP, Raff MC. Studies on cultured rat Schwann cells. II. Comparison with a rat Schwann cell line. In Vitro. 1979; 15:772-778. [PubMed: 230150]

24. Zigmond SH, Hirsch JG. Leukocyte locomotion and chemotaxis. New methods for evaluation, and demonstration of a cell-derived chemotactic factor. J Exp Med. 1973; 137:387-410. [PubMed: 4568301]

25. Bacher M, Metz CN, Calandra T, Mayer K, Chesney J, Lohoff M, Gemsa D, Donnelly T, Bucala R. An essential regulatory role for macrophage migration inhibitory factor in T-cell activation. Proc Natl Acad Sci USA. 1996; 93:7849-7854. [PubMed: 8755565]

26. Wang HU, Anderson DJ. Eph family transmembrane ligands can mediate repulsive guidance of trunk neural crest migration and motor axon outgrowth. Neuron. 1997; 18:383-396. [PubMed: 9115733]

27. Walter J, Henke-Fahle S, Bonhoeffer F. Avoidance of posterior tectal membranes by temporal retinal axons. Development. 1987; 101:909-913. [PubMed: 3503703]

28. Cao L, Su Z, Zhou Q, Lv B, Liu X, Jiao L, Li Z, Zhu Y, Huang Z, Huang A, He C. Glial cell linederived neurotrophic factor promotes olfactory ensheathing cells migration. Glia. 2006; 54:536544. [PubMed: 16906542]

29. De Bellard ME, Rao Y, Bronner-Fraser M. Dual function of Slit2 in repulsion and enhanced migration of trunk, but not vagal, neural crest cells. J Cell Biol. 2003; 162:269-279. [PubMed: 12876276]

30. Fornaro M, Tos P, Geuna S, Giacobini-Robecchi MG, Battiston B. Confocal imaging of Schwanncell migration along muscle-vein combined grafts used to bridge nerve defects in the rat. Microsurgery. 2001; 21:153-155. [PubMed: 11494383]

31. Milner R, Wilby M, Nishimura S, Boylen K, Edwards G, Fawcett J, Streuli C, Pytela R, ffrenchConstant C. Division of labor of Schwann cell integrins during migration on peripheral nerve extracellular matrix ligands. Dev Biol. 1997; 185:215-228. [PubMed: 9187084]

32. Griesbeck O, Parsadanian AS, Sendtner M, Thoenen H. Expression of neurotrophins in skeletal muscle: quantitative comparison and significance for motoneuron survival and maintenance of function. J Neurosci Res. 1995; 42:21-33. [PubMed: 8531223] 
33. Young HM, Anderson RB, Anderson CR. Guidance cues involved in the development of the peripheral autonomic nervous system. Auton Neurosci. 2004; 112:1-14. [PubMed: 15233925]

34. Stewart AL, Anderson RB, Kobayashi K, Young HM. Effects of NGF, NT-3 and GDNF family members on neurite outgrowth and migration from pelvic ganglia from embryonic and newborn mice. BMC Dev Biol. 2008; 8:73. [PubMed: 18657279]

35. Barde YA. The nerve growth factor family. Prog Growth Factor Res. 1990; 2:237-248. [PubMed: 2133291]

36. Chao M, Casaccia-Bonnefil P, Carter B, Chittka A, Kong H, Yoon SO. Neurotrophin receptors: mediators of life and death. Brain Res Brain Res Rev. 1998; 26:295-301. [PubMed: 9651545]

37. Yamauchi J, Chan JR, Shooter EM. Neurotrophin 3 activation of TrkC induces Schwann cell migration through the c-Jun N-terminal kinase pathway. Proc Natl Acad Sci USA. 2003; 100:14421-14426. [PubMed: 14614136]

38. Paratcha G, Ledda F, Ibanez CF. The neural cell adhesion molecule NCAM is an alternative signaling receptor for GDNF family ligands. Cell. 2003; 113:867-879. [PubMed: 12837245]

39. Anton ES, Weskamp G, Reichardt LF, Matthew WD. Nerve growth factor and its low-affinity receptor promote Schwann cell migration. Proc Natl Acad Sci USA. 1994; 91:2795-2799. [PubMed: 8146193]

40. Yamauchi J, Chan JR, Shooter EM. Neurotrophins regulate Schwann cell migration by activating divergent signaling pathways dependent on Rho GTPases. Proc Natl Acad Sci USA. 2004; 101:8774-8779. [PubMed: 15161978]

41. Liu KL, Chuah MI, Lee KK. Soluble factors from the olfactory bulb attract olfactory Schwann cells. J Neurosci. 1995; 15:990-1000. [PubMed: 7869124]

42. Cacalano G, Farinas I, Wang LC, Hagler K, Forgie A, Moore M, Armanini M, Phillips H, Ryan AM, Reichardt LF, Hynes M, Davies A, Rosenthal A. GFRalpha1 is an essential receptor component for GDNF in the developing nervous system and kidney. Neuron. 1998; 21:53-62. [PubMed: 9697851]

43. Natarajan D, Marcos-Gutierrez C, Pachnis V, de Graaff E. Requirement of signalling by receptor tyrosine kinase RET for the directed migration of enteric nervous system progenitor cells during mammalian embryogenesis. Development. 2002; 129:5151-5160. [PubMed: 12399307]

44. Garratt AN, Voiculescu O, Topilko P, Charnay P, Birchmeier C. A dual role of erbB2 in myelination and in expansion of the Schwann cell precursor pool. J Cell Biol. 2000; 148:10351046. [PubMed: 10704452]

45. Britsch S, Li L, Kirchhoff S, Theuring F, Brinkmann V, Birchmeier C, Riethmacher D. The ErbB2 and ErbB3 receptors and their ligand, neuregulin-1, are essential for development of the sympathetic nervous system. Genes Dev. 1998; 12:1825-1836. [PubMed: 9637684]

46. Meyer D, Yamaai T, Garratt A, Riethmacher-Sonnenberg E, Kane D, Theill LE, Birchmeier C. Isoform-specific expression and function of neuregulin. Development. 1997; 124:3575-3586. [PubMed: 9342050]

47. Woldeyesus MT, Britsch S, Riethmacher D, Xu L, Sonnenberg-Riethmacher E, Abou-Rebyeh F, Harvey R, Caroni P, Birchmeier C. Peripheral nervous system defects in erbB2 mutants following genetic rescue of heart development. Genes Dev. 1999; 13:2538-2548. [PubMed: 10521398]

48. Mueller BK. Growth cone guidance: first steps towards a deeper understanding. Annu Rev Neurosci. 1999; 22:351-388. [PubMed: 10202543] 



Fig. 1.

SpL201 Schwann cell precursor line expresses different glia markers. SpL201 were cultured for one day before fixing and staining for different glia markers. All wells were counterstained with DAPI (blue) to visualize cell nuclei. a Not all SpL201 express nuclear Sox10 transcription factor (red arrows point to double labeled cells seen as purple, while blue arrows point to cells not positive for Sox10). b All SpL201 express RIP to some extent (green signal) while not all express S100 (red) marker of glial cell (blue arrows point to cells negative for S100). c Most of the SpL201 expressed high levels of neural crest/ Schwann cell marker p75 NGF receptor (red). d Not all the SpL201 expressed high levels of GFAP, but all cells expressed it some levels of GFAP (white arrow) 

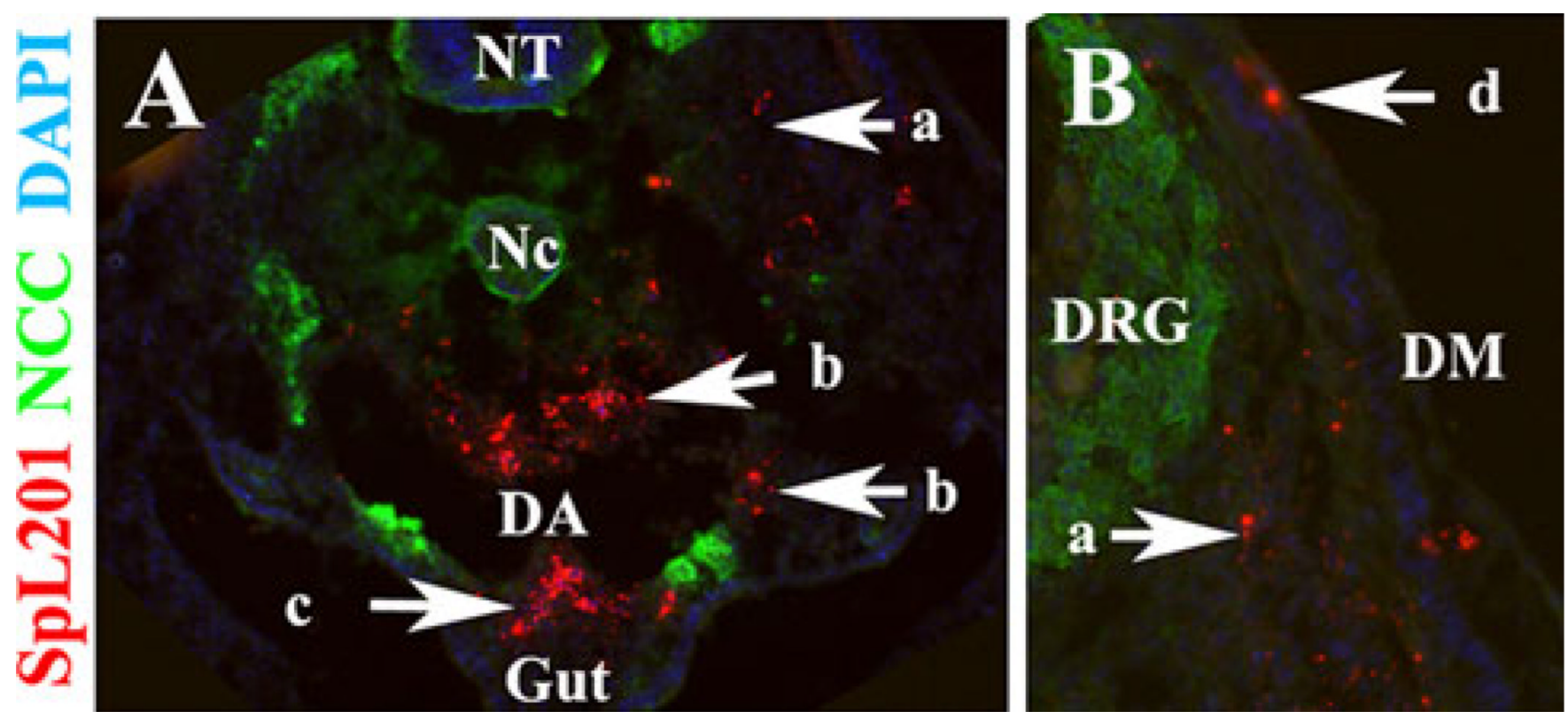

Fig. 2.

SpL201 cells migrate along neural crest cells pathways. SpL201 mouse Schwann cells were DiI labeled and injected in HH15 chicken embryo for $24 \mathrm{~h}$. DiI-positive cells were found along the ventromedial pathway (arrow a), the dorsal aorta (arrow $b$ ), entering the gut (arrow c) and dorsomedial pathway (arrow d). SpL201 are in red fluorescent, neural crest cells in green fluorescence for HNK1 and cell nuclei in blue for DAPI. $N T+$ neural tube, $N c$ = notochord, $D A=$ dorsal aorta,$D R G=$ dorsal root ganglion and $D M=$ dermomyotome 


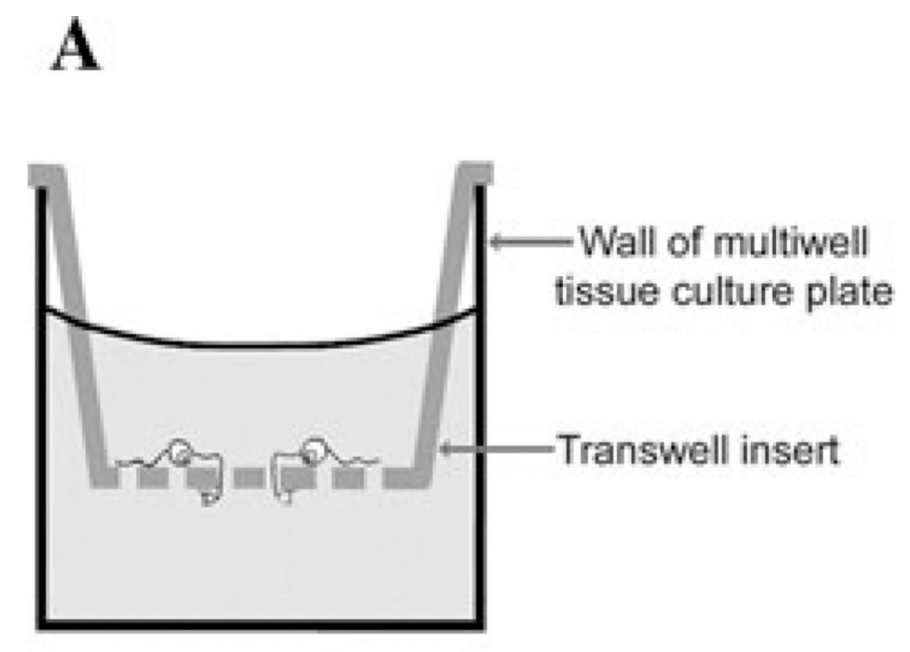

\section{1. neural crest were placed onto the transwell insert}

\section{2. factors to be tested were diluted in DMEM}

3. after 5-6 hours of incubation. the number of cells that had crossed the membrane was counted.

B

Percentage of Chemoattraction

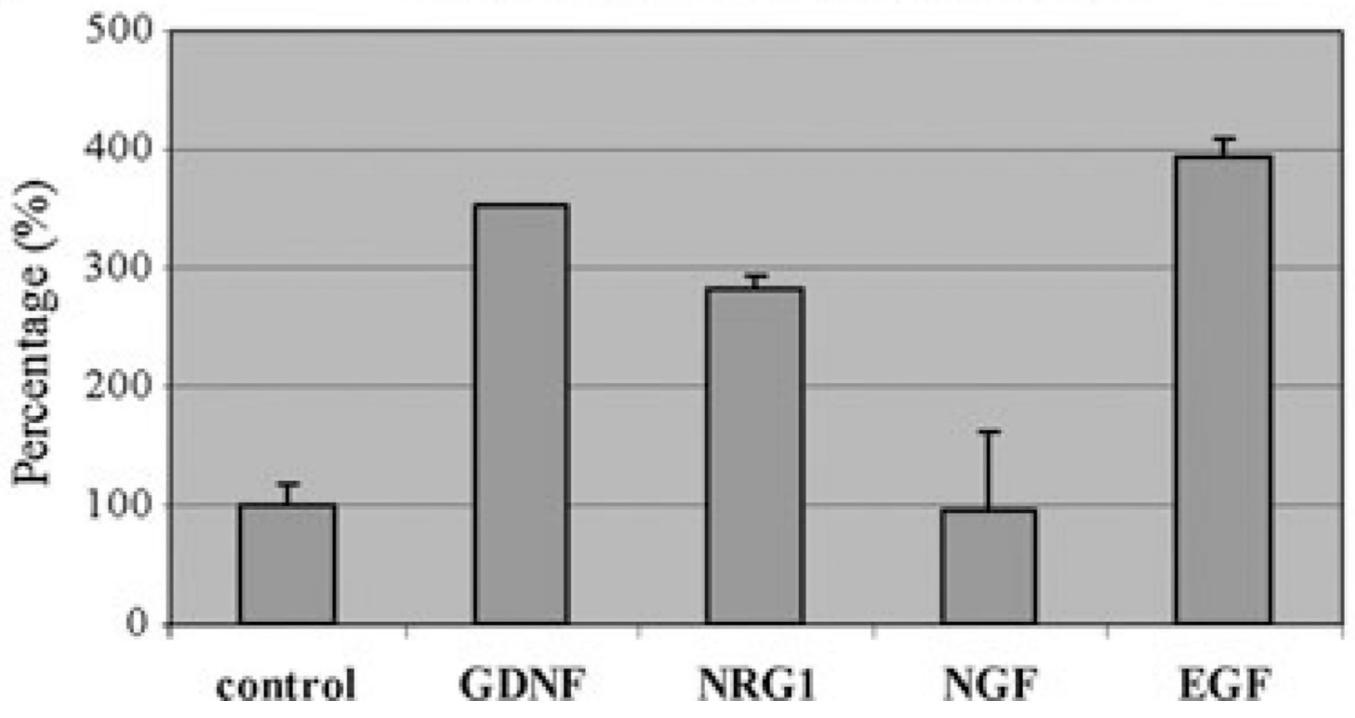

Fig. 3.

GDNF, NRG1 and EGF attract Schwann cell precursors SpL201t cells. a Cartoon of the chemotaxis experiments: cells (125,000 cells per well) were cultured for $5 \mathrm{~h}$ on top of fibronectin coated chemotaxis transwells with neurotrophins present in the lower chamber $(200 \mathrm{ng} / \mathrm{ml})$. After $5 \mathrm{~h}$ cells on the upper filter are removed and lower ones counted. b Shows a graph that combines results from 4 experiments as percentage of cells that migrated towards neurotrophins $( \pm$ SEM). Compared with control conditions. The number of cells in the wells containing GDNF, NRG1 and EGF was more than double the amount in the wells without them or with NGF $(P<0.03$ for GDNF, $P<0.008$ for NRG1 and EGF) 


\section{A}

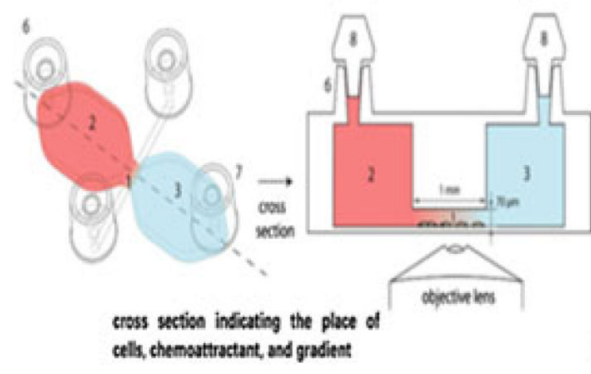
4. Cells incubate overnight while a linear chemical gradient is established.

5. As Cells are exposed to the gradient, they are imaged with time-lapse for $3 \mathrm{hrs}$.

1. Small Ibidi u-slides are loaded with the cell type of choice (Area 1; Fig. 1).

2. Appropriate media is added homogeneously throughout the chamber (Areas 1, 2, \&3).

3. A Neurotrophin of choice is added to one of the reservoirs (Area 2 or 3 )
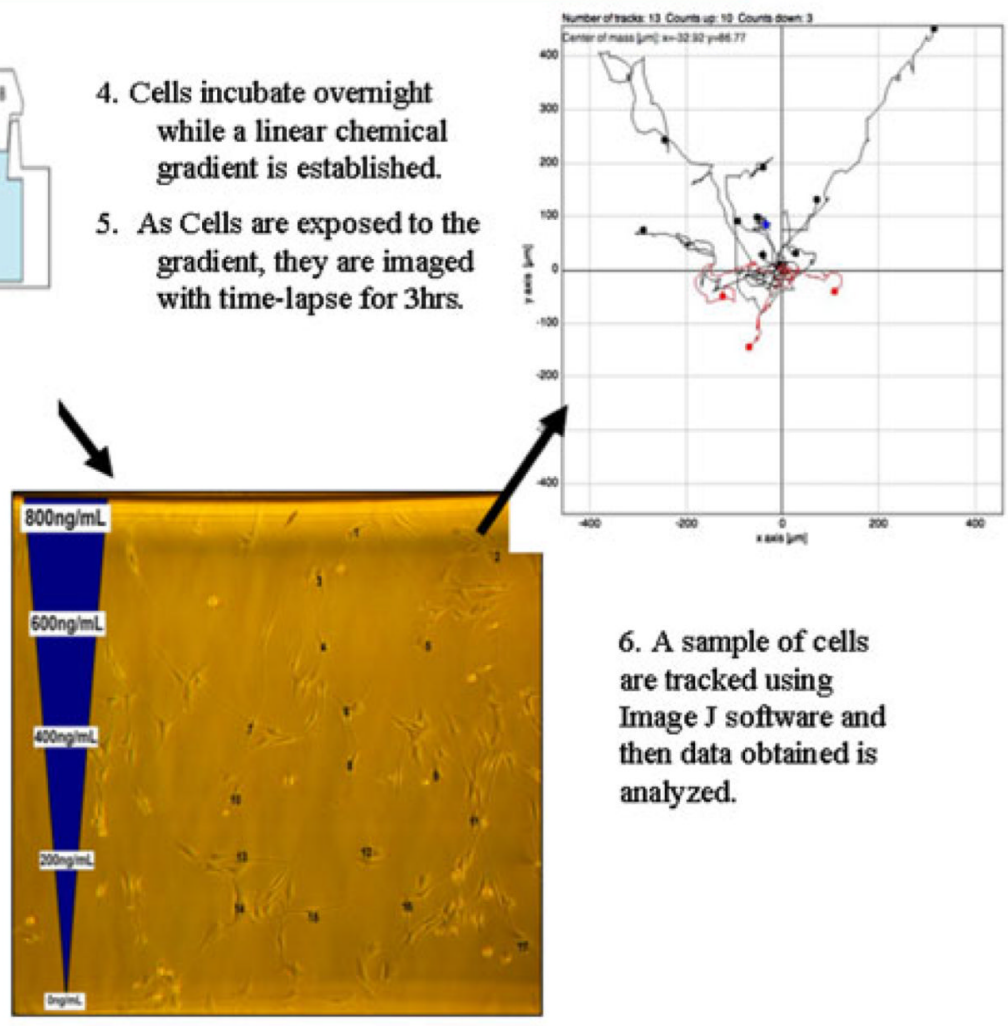

B

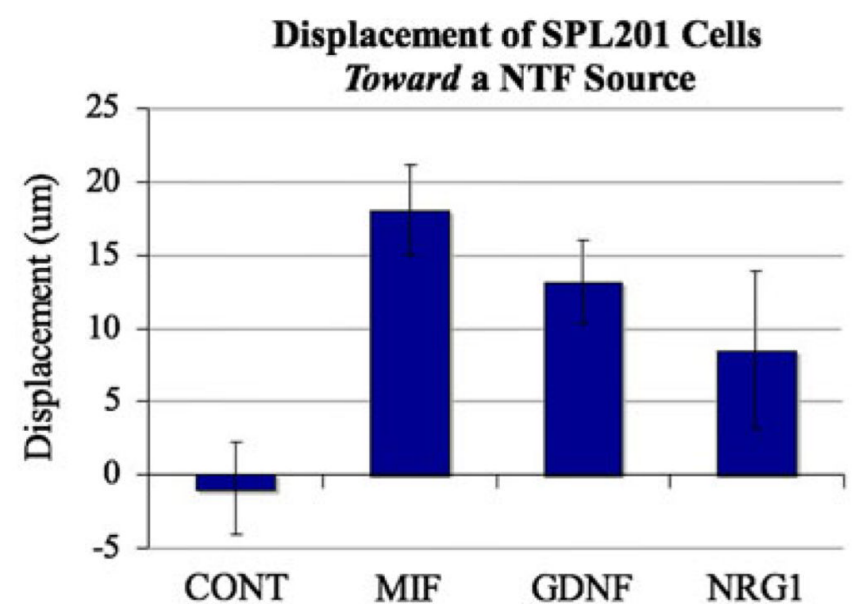

Fig. 4.

GDNF and NRG1 attract a Schwann cell precursor line SpL201 cells. a cartoon describing the steps and method of the Ibidi chamber assay. b SpL201 cells were cultured overnight in ibidi $\mu$-slide chemotaxis chambers while an applied linear NTF gradient could be established in media containing $2.5 \%$ FBS. The following day the cells were filmed live in the chamber with time-lapse imaging at 90 s intervals for $3 \mathrm{~h}$ at $37^{\circ} \mathrm{C}$. The starting and end positions of numerous cells on the side of the channel closest to the NTF source were recorded. Displacement of each cell along the axis parallel to the gradient was then derived and the average for all cells measured for one chamber was treated as a statistical replicate. Higher displacement values reflect greater movement toward the NTF source, $n=5$ experiments. 
CONT $=100$ cells tracked, MIF $=78$ cells, GDNF $=73$ cells and NRG1 $=106$ cells. Error bars refer to the SEM. ANOVA with Dunnett's post-hoc test showed that MIF and GDNF were significantly different than the control treatment $(P<0.01$ and $P<0.05$ respectively) 


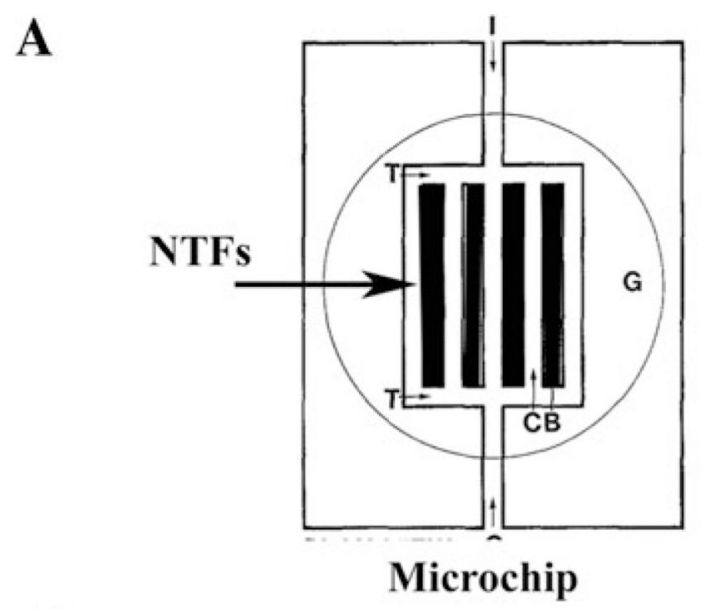

\section{B}
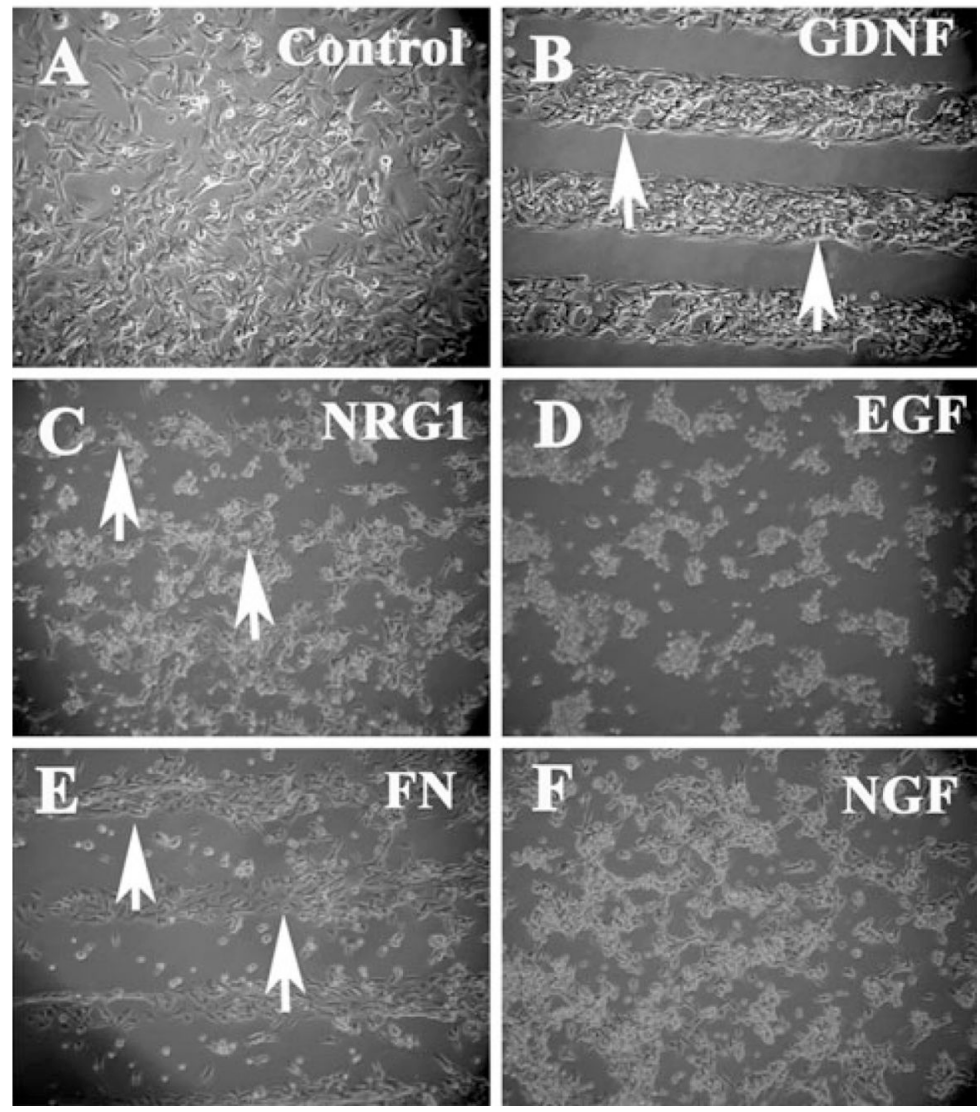

Fig. 5.

GDNF and NRG1 are preferential substrates for Schwann cell precursor line SpL201. a cartoon describing the microchip arrangement. b SpL201 cells were plated on top of microchips coated area $(\sim 5-7 \mathrm{ml})$ as a cell suspension in fibronectin solution, after $2 \mathrm{~h}$ to allow cell attachment cultures were fully covered with culture media (DMEM, 10\% FBS) and photographed after a total of $5 \mathrm{~h}$ post plating. SpL201 preferentially grew over/towards GDNF and NRG1 over this period of time (arrows). EGF and NGF did not elicit such a rapid response. Fibronectin micro-chip lanes were used as control 

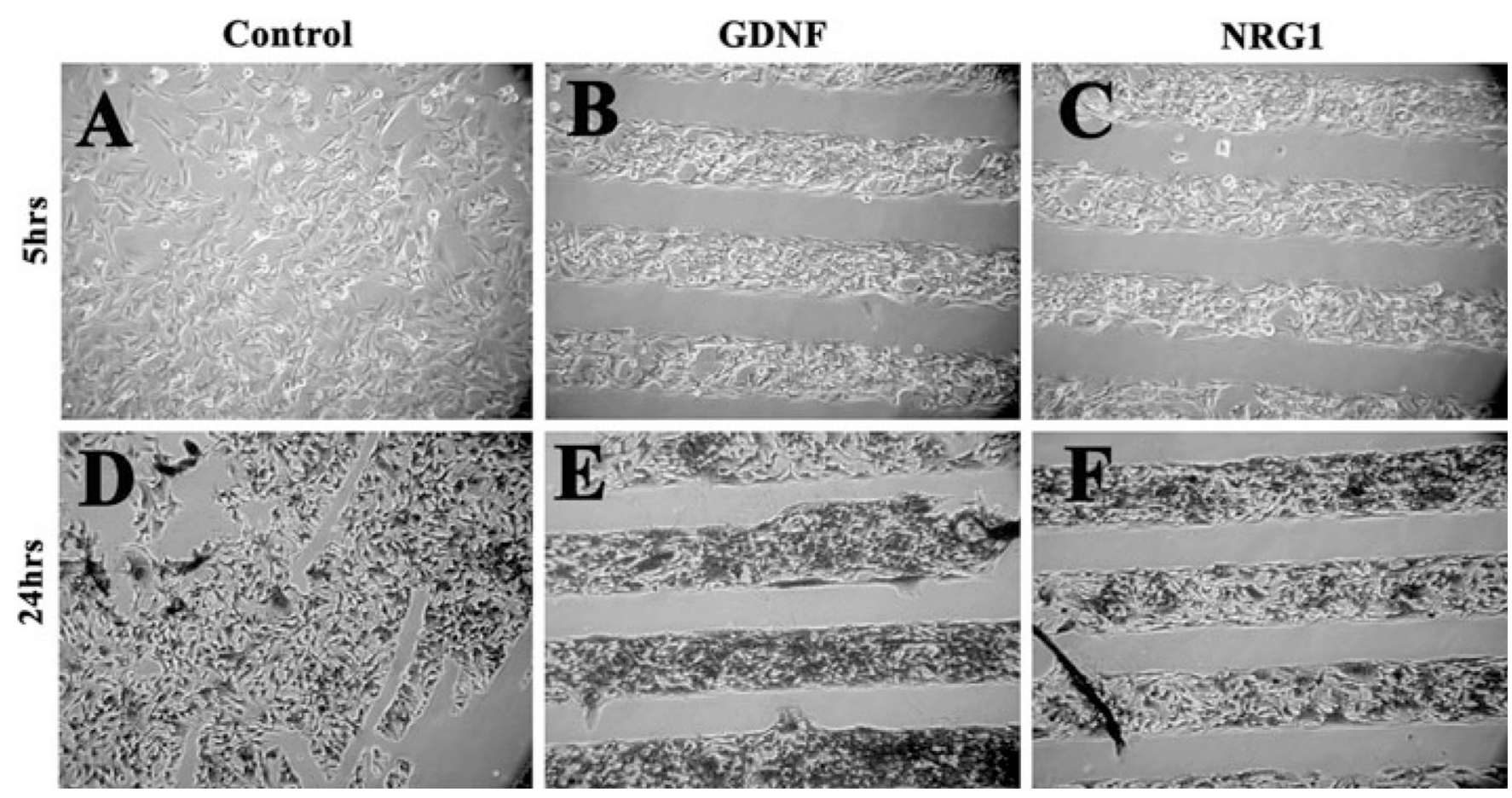

Fig. 6.

GDNF and NRG1 are preferential substrates for Schwann cell precursor line SpL201.

SpL201 cells were plated on top of microchips coated area $(\sim 5-7 \mathrm{ml})$ as a cell suspension in fibronectin solution, after $2 \mathrm{~h}$ to allow cell attachment cultures were fully covered with culture media (DMEM, 10\% FBS) and photographed after a total of 5 or $24 \mathrm{~h}$ post plating. SpL201 preferentially grew and remained over GDNF and NRG1 substrates over this period of time. GDNF panel in Fig. 5b is from the same experiment as panel B in Fig. 6. NRG1 panels correspond to two different experiments 


\section{Percentage of cells in the Wounds}



Fig. 7.

Neurotrophins stimulate migration of Schwann cells. SpL201 mouse Schwann cells were plated on fibronectin coated tissue culture dishes and the following day the cell monolayer was wounded with a pipette tip. Wounds were stopped after $5 \mathrm{~h}$. Cultures were done in the presence $(+\mathrm{FBS}, 5 \%)$ or absence (-FBS) of fetal bovine serum (FBS). Chart shows results for all combined experiments $(N=5)$ done with duplicates, error bars are standard deviation. NRG1, NGF and GDNF all stimulated the motility of SpL201 in the absence of serum. Slit2 was used as a positive control as conditioned media from 293HEK secreting Slit 2 cells 